\title{
Karakteristik Biokomposit Edible Film dari Campuran Kitosan dan Pektin Limbah Kulit Pisang Kepok (Musa acuminata)
}

Characteristic of Edible Film Biocomposites from mixed Chitosan and Pectin Saba Banana (Musa acuminate) Peel Waste

\author{
Daril Ridho Zuchrillah ${ }^{1)}$, Lily Pudjiastuti ${ }^{1)}$, Niniek Fajar Puspita ${ }^{1)}$, Afan Hamzah ${ }^{1)}$, \\ Achmad Dwitama Karisma ${ }^{1)}$, Agus Surono ${ }^{1)}$, Saidah Altway ${ }^{1)}$, Liana Ardiani ${ }^{1)}$, Nur \\ Azizatur Rohmah ${ }^{1)}$, Eva Oktavia Ningrum ${ }^{1}$ ) \\ ${ }^{1)}$ Institut Teknologi Sepuluh Nopember, Departemen Tenik Kimia, Fakultas Vokasi, Kampus \\ ITS Sukolilo, Surabaya, 60111, Indonesia \\ *email: eva-oktavia@chem-eng.its.ac.id
}

Received: 02/06/20; Revised: 17/06/20; Accepted: 20/06/20

\begin{abstract}
Abstrak
Kemasan plastik banyak digunakan pada industri makanan dan minuman di Indonesia karena praktis dan mudah. Namun ${ }_{2}$ disisi lain ini merupakan bencana bagi lingkungan karena plastik merupakan bahan yang sulit terurai (nondegradable). Edible film merupakan salah satu alternatif yang dapat dipertimbangkan untuk menggantikan kemasan plastik. Tujuan dari penelitian ini adalah memanfaatkan kitosan dari limbah cangkang rajungan dan pektin dari limbah kulit pisang kepok sebagai bahan baku pembuatan edible film. Kitosan diperoleh dari proses degreasing, deproteinasi, demineralisasi dan deasetilasi cangkang rajungan. Pektin diperoleh dari proses hidrolisis kulit pisang kepok. Edible film yang berbasis kitosan dan pektin dibuat melalui proses blending dengan ratio (K:P) 100:0; 60:40; 50:50: 40:60 dan 0:100. Analisis karakteristik yang dilakukan meliputi warna, transparan, ketebalan, kelarutan dalam air, laju transmisi uap air (WVTR), kadar air, swelling degree, biodegradabilitas, dan aktivitas antimikroba. Hasil penelitian menunjukkan edible film kitosan dan pektin yang paling optimal adalah ratio 50:50.
\end{abstract}

Kata kunci: Biokkomposit, bioplastik, edible film, kitosan, pektin

\begin{abstract}
Plastic is utilized extensively as food and beverages package in Indonesia since it is inexpensive and flexible. However, it is not environmentally friendly due to its non-degradable characteristic. Bioplastic can be attractive solution. The objective of this study was to utilized pectin from banana peels waste and chitosan from crab shell waste as edible film. Chitosan was obtained with degreasing, deproteinization, demineralization, and deacetylation process of crab shell waste. Pectin was attained from banana peels waste hydrolysis. The Edible film was created by blending process of chitosan and pectin with (C:P) 100:0; 60:40; 50:50; 40:60 and 0:100 weight ratio. Characteristic analysis including color, transparency, thickness, solubility in water, water vapor transmission rate (WVTR), water content, swelling degree, and biodegradability. Antimicrobial activity had also been studied. The highest characteristic in transparency, solubility, WVTR, swelling degree and biodegradability was attained in 50:50 (w:w) composition of chitosan and pectin.
\end{abstract}

Keywords: Biocomposite, bioplastic, chitosan, edible film, pectin 
Daril Ridho Zuchrillah, Lily Pudjiastuti, Niniek Fajar Puspita, Afan Hamzah, Achmad Dwitama Karisma, Agus Surono, Saidah Altway, Liana Ardiani, Nur Azizatur Rohmah, Eva Oktavia Ningrum*)

Karakteristik Biokomposit Edible Film dari Campuran Kitosan dan Pektin Limbah Kulit Pisang Kepok (Musa acuminata)

\section{PENDAHULUAN}

Berkembangnya industri makanan dan minuman di Indonesia dalam kurun waktu 5 tahun terakhir meningkat pesat diiringi dengan penggunaan kemasan plastik sebagai bahan pengemas makanan dan minuman. Penggunaan produk kemasan makanan berbasis plastik yang sifatnya mudah dibentuk, ringan, kuat dan tentu harganya yang terjangkau ini diproduksi dari polimer petrokimia (Kamsiati dkk., 2017). Banyak campuran zat kimia yang ditambahkan pada plastik tersebut seperti senyawa bisphenol-A (BPA) yang bersifat karsinogenik, menyebabkan kerusakan ekosistem lingkungan karena bahan tersebut tidak terurai sempurna (non-biodegradable) (Homez-Jara dkk., 2018).

Perlu ada upaya pengembangan kemasan makanan dan minuman yang ramah lingkungan yang bersifat mudah terurai (biodegradable) dan aman bagi kesehatan. Bioplastik berupa lapisan tipis yang bisa diaplikasikan sebagai kemasan makanan dan juga meningkatkan daya simpan makanan yaitu edible film. Edible film berfungsi sebagai penghambat terhadap transfer massa (kelembaban, oksigen, gas dan zat-zat terlarut yang terlibat dalam proses respirasi) dan sebagai pelindung makanan dari mikroba (Dangaran $d k k .$, 2009) Edible film terbuat dari polisakarida utama seperti kitosan, pati, alginat, karagenan, selulosa termodifikasi, pektin dan penambahan plasticizer (Dhanapal dkk., 2012).

Indonesia merupakan negara yang memiliki hasil laut melimpah akan sumbersumber kitosan seperti rajungan dan udang. Rajungan merupakan salah satu komoditas ekspor dalam bentuk rajungan beku dan kemasan daging dalam bentuk kaleng. Nilai ekspor daging rajungan pada tahun
2017 tercatat mencapai $15.867 .016 \mathrm{~kg}$. Dari proses pengambilan daging rajungan akan menghasilkan limbah berupa cangkang sekitar 40-60\% dari total berat rajungan. Sebagian besar limbah cangkang rajungan akan dibuang ke laut atau dijadikan pakan ternak saja (Rochima, 2014).

Cangkang rajungan mengandung persentase kitin yang merupakan senyawa awal sebelum diproses deasetilasi menjadi kitosan sebanyak $71 \%$. Hal tersebut merupakan bahan biokomposit yang potensial dibuat menjadi bahan dasar edible film. Kitosan merupakan suatu polimer multifungsi karena mengandung tiga jenis gugus fungsi yaitu asam amino, gugus hiroksil primer dan sekunder. Adanya gugus fungsi tersebut menyebabkan kitosan mempunyai reaktifitas yang tinggi (Homez-Jara $d k k$., 2018). Dalam penggunaanya, kitosan memiliki karakteristik sebagai bahan biokomposit yang dapat dijadikan bahan baku edible film.

Selain kitosan, senyawa pektin juga dapat digunakan sebagai edible film. Pektin merupakan komponen serat senyawa polisakarida kompleks dengan komponen utama asam D-galakturonat yang dapat diperoleh dari lapisan lamela tengah dan dinding sel primer pada tanaman seperti limbah kulit buah-buahan (Sirotek $d k k$., 2004). Kulit pisang kepok memiliki kandungan seyawa pektin sebesar 0,9\% dari berat kering. Hal tersebut disebabkan oleh besarnya pisang, sehingga kandungan karbohidrat semakin banyak dan mempengaruhi banyaknya kandungan protopektin yang apabila terhidrolisa menjadi pektin (Tuhuloula $d k k$., 2013).

Pektin dimanfaatkan sebagai bahan pengental dan pembentuk gel pada industri pangan fungsional. Parameter penentu 
kemampuan gel pada pektin ditentukan dalam kadar metoksil. Kadar metoksil adalah jumlah metanol yang terdapat di dalam pektin dan penentu sifat fungsional larutan pektin serta dapat mempengaruhi struktur dari gel pektin yang terbentuk (Madjaga $d k k .$, 2017).

Pembuatan edible film ini perlu penambahan plasticizer untuk meningkatkan daya kuat tarik agar memenuhi standar dan laju transmisi uap air yang tinggi. Ketika penambahan gliserol 10\% sebagai plasticizer didapatkan hasil peningkatan kejernihan dan persen elongasi edible film, tetapi menurunkan kuat tarik edible film (Baron dkk., 2017). Pada penelitian ini telah dilakukan pembuatan edible film berbasis biokomposit kitosan dan pektin, dan karakterisasi untuk mengetahui tingkat biodegradibilitas produk edible film yang dihasilkan sehingga diharapkan sebagai bahan pengganti kemasan plastik yang tidak merusak lingkungan sekitar.

\section{METODE PENELITIAN}

Penelitian ini terbagi menjadi beberapa tahapan yaitu isolasi kitosan dan pektin, pembuatan edible film dan karakterisasi. Bahan yang digunakan adalah cangkang rajungan, kulit pisang kepok, asam asetat glasial 100\%, gliserol, aquades dan $\mathrm{HCl}$.

\section{Isolasi Kitosan dari Cangkang Rajungan}

Kitosan yang digunakan berasal dari cangkang rajungan yang telah direbus selama 1 jam pada suhu $80{ }^{\circ} \mathrm{C}$. Selanjutnya, dicuci dengan aquades dan dikeringkan di bawah sinar matahari selama 2 hari. Tahap berikutnya yaitu resizing untuk mendapatkan ukuran yang lebih kecil dengan blender. Selanjutnya padatan hasil tersebut direndam dalam larutan $\mathrm{NaOH} 4 \%$ dengan ratio 1:5 (w/v) selama 12 jam disertai pengadukan dan pemanasan pada suhu $100{ }^{\circ} \mathrm{C}$. Perendaman crude kitin hasil deproteinasi dengan aquadest diperlukan hingga netral.

Setelah perendaman dengan $\mathrm{NaOH}$, dilanjutkan perendaman dengan larutan $\mathrm{HCl} 2 \mathrm{~N}$ dengan ratio 1:5 (w/v) selama 12 jam disertai pengadukan dan pemanasan pada suhu $100{ }^{\circ} \mathrm{C}$. Hasil demineralisasi direndam dengan aquadest hingga netral. Tahapan terakhir yaitu deasetilasi, padatan hasil tersebut direndam dengan $\mathrm{NaOH} 70 \%$ dengan ratio 1:2,5 (w/v) selama 12 jam. Setelah itu dicuci hingga netral dan dikeringkan pada suhu $105{ }^{\circ} \mathrm{C}$ selama 24 jam.

\section{Isolasi Pektin dari Kulit Pisang Kepok}

Limbah kulit pisang kepok dihaluskan dan dihidrolisis dengan menambahkan akuades dan $\mathrm{HCl} 0,05 \mathrm{~N}$ selama 2 jam pada suhu $80{ }^{\circ} \mathrm{C}$ untuk menurunkan $\mathrm{pH}$ menjadi 1,5 . Selanjutnya dilakukan penyaringan dan filtrat dikentalkan dengan pemanasan pada suhu $80{ }^{\circ} \mathrm{C}$.

Tahapan berikutnya yaitu pemurnian pektin dengan penambahan etanol $96 \%$ sebanyak 1:1 dengan volume filtrat pektin dan didiamkan selama 24 jam. Penyaringan endapan pektin dilakukan beberapa kali agar pektin yang didapat lebih optimal. Selanjutnya endapan pektin dicuci dengan etanol $96 \%$ (w) dan dikeringkan pada suhu $40{ }^{\circ} \mathrm{C}$ selama 10 jam.

\section{Pembuatan Edible Film}

Kitosan dan pektin hasil isolasi ditimbang dengan perbandingan persen massa kitosan (K) dan pektin (P) yaitu 100:0; 60:40; 50:50; 40:60 dan 0:100. 
Karakteristik Biokomposit Edible Film dari Campuran Kitosan dan Pektin Limbah Kulit Pisang Kepok (Musa acuminata)

Selanjutnya kitosan didispersikan ke dalam $100 \mathrm{~mL}$ asam asetat glasial $1 \%$ dan pektin ke_dalam aquadest $100 \mathrm{~mL}$ (Chan $d k k$., 2013). Selanjutnya mencampurkan kedua larutan dispersi dengan menambahkan $\mathrm{HCl}$ 0,3 N $100 \mathrm{ml}$ untuk menurunkan nilai $\mathrm{pH}$ dari larutan pembentuk film karena kedua biokomposit tersebut tercampur homogen pada kisaran nilai pH 3-6 (Nordby $d k k$., 2003). Lalu, menambahkan gliserol $0,2 \mathrm{~g} / \mathrm{g}$ biokomposit kedalam larutan pembentuk film yang bertujuan untuk meningkatkan fleksibiltas dari edible film.

Selanjutnya larutan pembentuk film disaring untuk memisahkannya dari zat yang tidak terlarut. Hasil saringan tersebut dicetak dan dikeringkan pada suhu konstan $50 \quad{ }^{\circ} \mathrm{C}$ selama $48-76$ jam. Setelah dikeringkan, edible film disimpan dalam desikator selama 2 hari sebelum dilakukan karakterisasi.

\section{Karakterisasi Edible Film}

Karakterisasi edible film berupa warna, transparan, ketebalan, kelarutan dalam air, laju transmisi uap air (WVTR), kadar air, swelling degree, biodegradabilitas dan analisis aktivitas antimikroba.

\section{a. Kelarutan dalam Air}

Analisis kelarutan dalam air diawali dengan menghitung berat sampel edible film dan direndam dengan air. Sampel yang tidak larut dioven pada suhu $100{ }^{\circ} \mathrm{C}$ selama 24 jam dan ditimbang. Kelarutan dalam air dihitung dalam satuan persen (Baron $d k k .$, 2017).

\section{b. Laju transmisi uap air (WVTR)}

Laju transmisi uap air edible film dilakukan pada cawan berisi sampel yang telah ditimbang dan dikondisikan pada suhu ruangan $25{ }^{\circ} \mathrm{C}$, Relative Humidity $75 \%$ selama 24 jam. Menimbangnya setiap hari pada jam sama selama 7 hari. Lalu membuat grafik hubungan antara pertambahan berat dan waktu (ASTM E 96, 1995).

\section{c. Kadar Air}

Analisis kadar air dilakukan dengan cara mengeringkan cawan porselen menggunakan oven pada suhu $105{ }^{\circ} \mathrm{C}$ selama 30 menit. Cawan tersebut diletakkan di dalam desikator selama 30 menit hingga suhu ruang. Kemudian menimbang sampel dan cawan. Memasukkan ke dalam oven dengan suhu $105{ }^{\circ} \mathrm{C}$ selama 4 jam lalu dimasukkan ke dalam desikator kemudian ditimbang (Horwitz \& Latimer, 2005).

\section{d. Swelling Degree}

Analisis Swelling Degree bertujuan untuk mengetahui tingkat penggembungan pada edible film. Langkah pertama yaitu memasukkan sampel hasil dari analisa kadar air ke dalam $50 \mathrm{ml}$ aquadest kemudian didiamkan selama 24 jam. Meniriskan sampel dengan tisu kemudian menimbangnya kembali dan mencatat massa akhir sampel (Baron $d k k$., 2017).

\section{e. Biodegradabilitas}

Analisa biodegradabilitas dengan penambahan bakteri EM4 (Effective Microorganism) yang telah diaktivasi. Sampel diamati dan menghitung lama terdegradasi dengan indikasi perubahan warna menjadi coklat. Analisis ini menghitung persen pengurangan massa pada edible film (Setiani $d k k$., 2013).

\section{f. Aktivitas Antimikroba}

Analisis aktivitas antimikroba pada edible film dilakukan dengan menginokulasikan bakteri Escherichia coli pada medium yang telah diletakkan edible film tersebut. Selanjutnya menginkubasi pada suhu ruangan selama 24 jam dan mengamati keberadaan zona bening disekitar sampel (Muin $d k k$., 2017). 
Daril Ridho Zuchrillah, Lily Pudjiastuti, Niniek Fajar Puspita, Afan Hamzah, Achmad Dwitama Karisma, Agus Surono, Saidah Altway, Liana Ardiani, Nur Azizatur Rohmah, Eva Oktavia Ningrum*)

Karakteristik Biokomposit Edible Film dari Campuran Kitosan dan Pektin Limbah Kulit Pisang Kepok (Musa acuminata)

\section{HASIL DAN PEMBAHASAN}

Kitosan yang diisolasi dari cangkang rajungan mendapatkan yield sebesar 22,5\% dan memiliki bentuk partikel berupa serpihan, kadar air sebesar $6 \%$, kadar abu sebesar $5,7 \%$, derajat deasetilasi $83,9 \%$ dan 3,68 cPs. Hasil derajat deasetilasi yang dihasilkan tergolong rendah. Hal tersebut dipengaruhi oleh perendaman, konsentrasi larutan dan suhu perendaman. Konsentrasi $\mathrm{NaOH}$, dan suhu perendaman yang semakin tinggi serta waktu yang semakin lama akan meningkatkan derajat deasetilasi kitosan yang dihasilkan (Tobing $d k k$., 2011).

Hasil hidrolisis pektin dari kulit pisang kepok yang dihasilkan dari penelitian ini mendapatkan yield sebesar $1,23 \%$, yang berwarna gelap, kadar air $10 \%$, kadar abu $7 \%$, berat ekivalen 2649,7 mg, kadar metoksil 4,06\%, kadar asam galakturonat $89,08 \%$ dan derajat esterifikasi 25,9\%. Kadar metoksil pektin rendah karena tidak semua gugus karboksil bebas teresterifikasi. Pektin dengan kadar metoksil rendah tidak dapat larut sempurna dalam air, tetapi dapat larut sempurna dalam larutan alkali dan oksalat (Tuhuloula $d k k ., 2013)$.

Berdasarkan Gambar 1, penambahan pektin menghasilkan warna yang lebih gelap (transparan keruh). Sedangkan pada komposisi $100 \%$ kitosan, daya transparan dan warna yang lebih baik daripada variabel komposisi biokomposit yang lainnya. Bahan baku pektin yang mudah teroksidasi membuat warna yang cenderung gelap dan memiliki kadar metoksil yang rendah pula (Ningrum $d k k$., 2019).

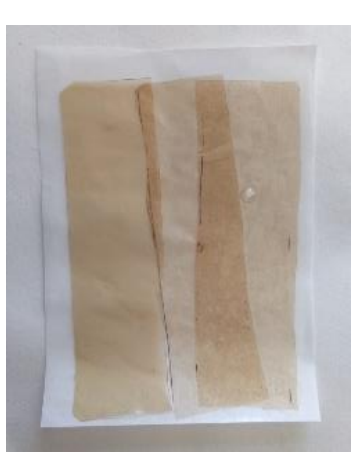

(a)

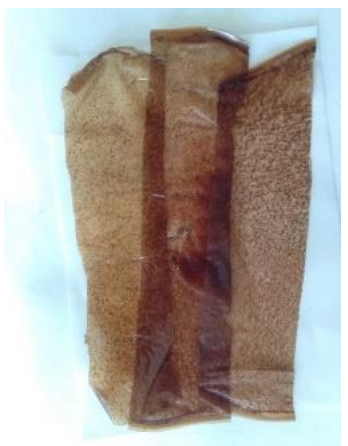

(c)

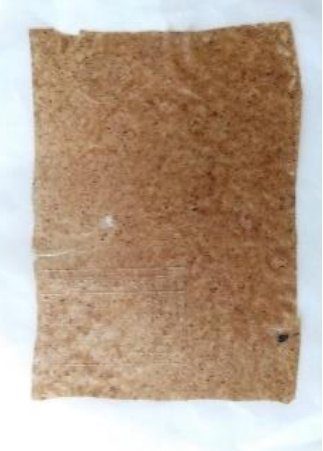

(b)

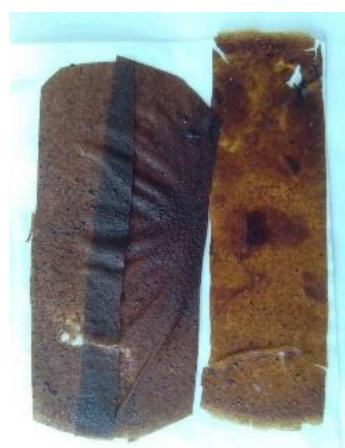

(d)

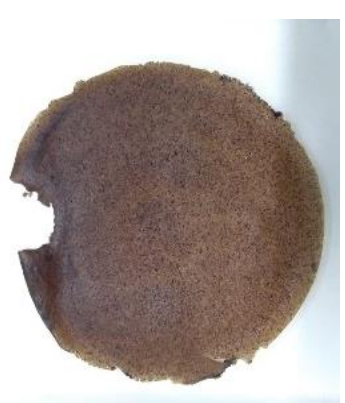

(e)

Gambar 1. Warna dan Transparan Edible film sintesis K:P (a) 100:0 (b) 60:40 (c) 50:50 (d) 40:60 (e)0:100 dari hasil sintesis.

Ketebalan merupakan salah satu parameter pada edible film untuk digunakan sebagai pengemasan produk makanan dan minuman. Ketebalan edible film dapat dipengaruhi oleh banyaknya total padatan dalam larutan pembentuk film, luas cetakan dan volume larutan saat percetakan. Semakin besar volume dan semakin banyak total padatan dalam bentuk larutan pembentuk film maka 
Karakteristik Biokomposit Edible Film dari Campuran Kitosan dan Pektin Limbah Kulit Pisang Kepok (Musa acuminata)

edible film yang dihasilkan akan semakin tebal (Suprioto, 2010). Pada Gambar 2, diketahui bahwa komposisi edible film kitosan dan pektin 50:50 memiliki ketebalan yang paling tebal. Ketebalan edible film memenuhi standar ketebalan edible film menurut Japanese Industrial Standart (JIS) yaitu maksimal 0,25 mm (Putra $d k k ., 2017)$.

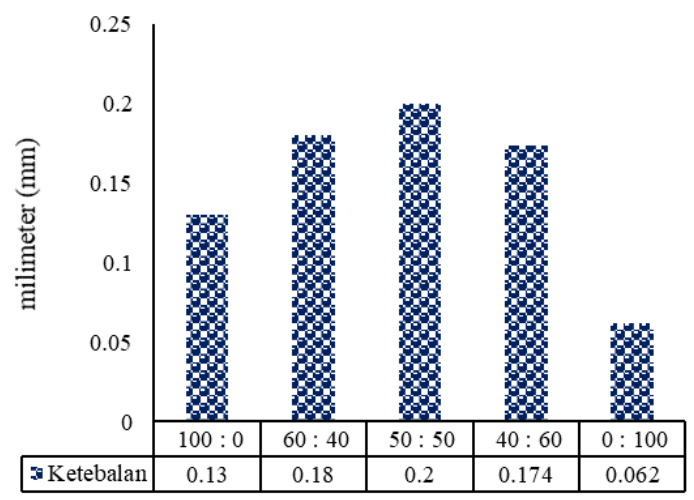

Gambar 2. Ketebalan edible film kitosan dan pektin sintesis

Dalam industri kemasan makanan, migrasi uap air dan oksigen pada edible film sangat penting dalam mendesain kemasan yang mampu menjaga kualitas bahan yang dikemas. Parameter yang digunakan adalah laju transmisi uap air (WVTR) dan kelarutan dalam air. Edible film yang memenuhi syarat menurut JIS 1975 yaitu maksimal $10 \mathrm{~g} / \mathrm{hari} / \mathrm{m}^{2}$ (Santoso $d k k ., 2012)$

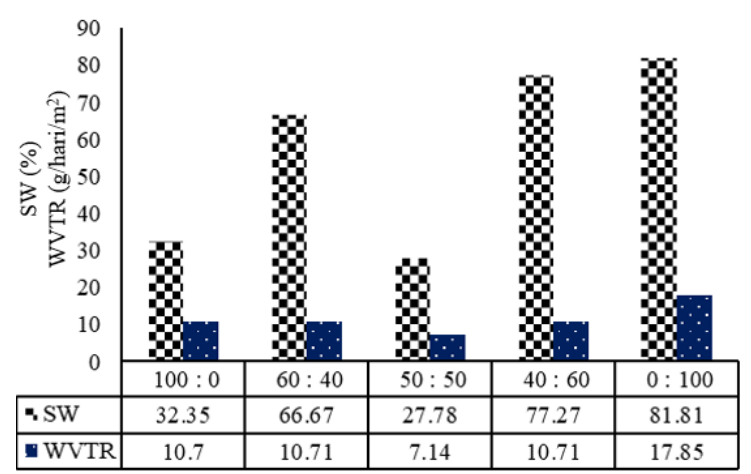

Gambar 3. Analisis Kelarutan dalam air (SW) dan WVTR sintesis
Gambar 3 menunjukkan bahwa edible dengan komposisi kitosan dengan pektin 50:50 saja yang memiliki nilai WVTR sesuai standar JIS 1975, yaitu $<10$ $\mathrm{g} /$ hari $/ \mathrm{m}^{2}$. Hal tersebut disebabkan oleh makin rapatnya matriks film. Edible film yang tersusun dari biokomposit kitosan lebih banyak memiliki nilai WVTR lebih rendah karena adanya sifat hidrofobik dari kitosan. Sedangkan penambahan biokomposit berupa pektin yang bersifat hidrofilik dapat meningkatkan kelarutan dalam air dari edible film (Baron $d k k$., 2017). Pada variabel yang lain didapatkan nilai WVTR yang lebih besar dari ketentuan menurut JIS. Hal tersebut disebabkan oleh suhu pengeringan dan kondisi fisik dari film. Suhu pengeringan yang terlalu tinggi menyebabkan cacat pada edible film seperti lubang dan ketebalan tidak rata (Rhim \& Shellhammer, 2005).

Selanjutnya adalah analisis swelling degree yang merupakan kemampuan edible film untuk menggembung dalam suatu larutan. Berdasarkan Gambar 4, hasil analisis edible film dengan komposisi kitosan lebih kecil memiliki kecenderungan nilai swelling degree makin tinggi. Hal tersebut dikarenakan adanya sifat dari kitosan yang hidrofobik.

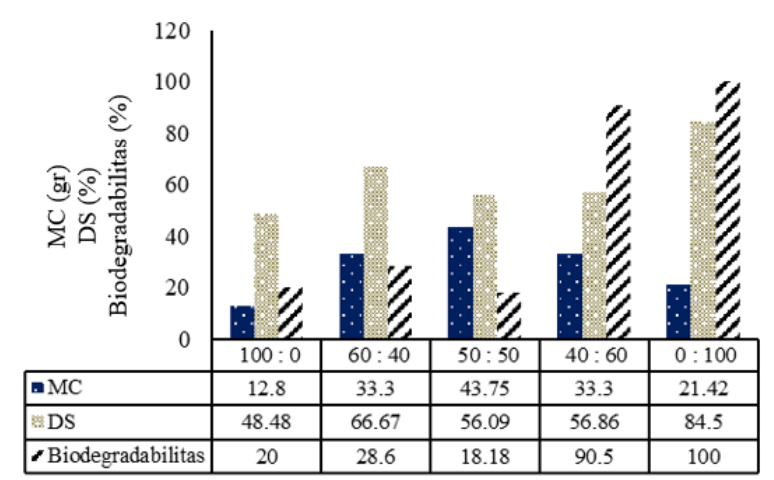

Gambar 4. Analisis kadar air (MC), swelling degree (DS), biodegradabilitas edible film sintesis 
Karakteristik Biokomposit Edible Film dari Campuran Kitosan dan Pektin Limbah Kulit Pisang Kepok (Musa acuminata)

Analisis biodegradabilitas edible film dilakukan untuk mengetahui suatu edible film dapat terurai dengan baik di lingkungan dengan proses enzimatik yang menggunakan bakteri EM4 sebagai bakteri yang akan menguraikan dengan tanah. Pada Gambar 4 menunjukkan bahwa edible film dengan komposisi pektin lebih besar memiliki tingkat biodegradabilitas yang lebih besar daripada edible film dari kitosan. Begitu juga dengan kadar air dalam edible film, yang disebabkan oleh pektin yang merupakan senyawa hidrofilik (Baron $d k k ., 2017$ ).

Analisis terakhir yaitu analisa mikroba untuk mengetahui aktivitas mikroba yang dapat menyebabkan proses pembusukan pada makanan. Untuk itu penambahan antibakteri dalam pembuatan edible film sangat penting. Dalam pengujian aktivitas antimikroba yang telah dilakukan bakteri yang digunakan adalah bakteri Esherichia coli.

Uji aktivitas antibakteri dengan komposisi edible film 60:40 menunjukkan penampakan zona hambat yang paling luas dibandingkan dengan komposisi edible film lainnya yang dapat dilihat pada Gambar 5. Zona hambat yang terbentuk tidak terlalu luas, yang mengindikasikan bahwa edible film dari kitosan dan pektin belum mampu melawan aktivitas bakteri Escherichia coli secara optimal.

Edible film yang mengandung kitosan sebenarnya dapat berperan sebagai antibakteri. Namun kitosan yang dihasilkan dari isolasi cangkang rajungan hanya memiliki derajat deasetilasi sebesar 83,9\%. Sedangkan kitosan dapat diaplikasikan sebagai antimikroba harus memiliki derajat deasetilasi 92\% keatas (Rochima, 2014). Sehingga kedepannya perlu meningkatkan derajat deasetilasi kitosan cangkang rajungan.

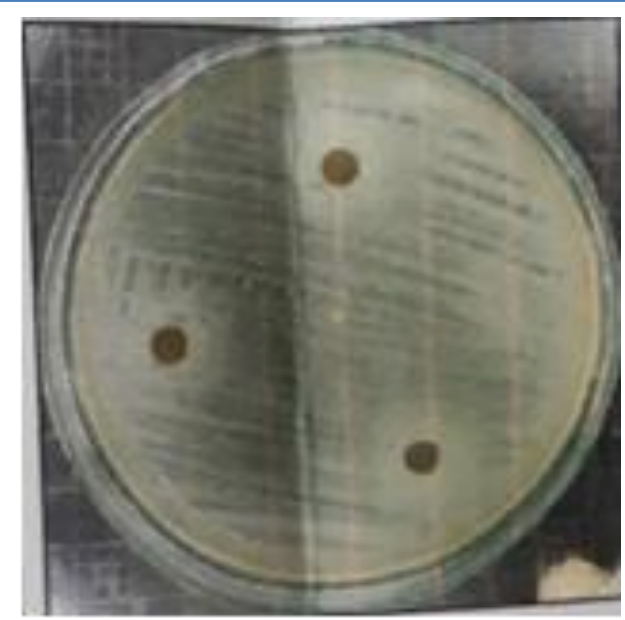

Gambar 5. Analisis antimikroba edible film sintesis 60:40

\section{KESIMPULAN}

Edible film dari biokomposit yang paling optimal pada komposisi kitosan dan pektin 50:50 dengan karakteristik ketebalan 0,2 mm, kelarutan dalam air 27,78\%, WVTR 7,14 g/hari/m², kadar air 43,75, swelling degree 56,09\%. Namun tingkat biodegradabilitas masih rendah yaitu sebesar $18,18 \%$ dan belum menunjukkan aktivitas antibakteri secara signifikan karena derajat deasetilasinya yang masih rendah.

\section{ACKNOWLEDGMENTS}

Penelitian ini didanai oleh hibah Penelitian Dasar Unggulan Perguruan Tinggi 2020 (1187/PKS/ITS/2020) dari Deputi Bidang Penguatan Riset dan Pengembangan KEMENRISTEK/BRIN.

\section{DAFTAR RUJUKAN}

ASTM E 96. (1995). Standard Test Methods for Water Vapor Transmission of Materials, E 96/E 96M - 05. $i, 1-8$.

Baron, R. D., Pérez, L. L., Salcedo, J. M., Córdoba, L. P., \& Sobral, P. J. do A. (2017). Production and characterization of films based on blends of chitosan from blue crab 
Karakteristik Biokomposit Edible Film dari Campuran Kitosan dan Pektin Limbah Kulit Pisang Kepok (Musa acuminata)

(Callinectes sapidus) waste and pectin from Orange (Citrus sinensis Osbeck) peel. International Journal of Biological Macromolecules, 98, 676683 ,

https://doi.org/10.1016/j.ijbiomac.201 7.02.004

Chan, M. Y., Husseinsyah, S., \& Sam, S. T. (2013). Corn Cob Filled Chitosan Biocomposite Films. Advanced Materials Research, 747, 649-652, https://doi.org/10.4028/www.scientif ic.net/AMR.747.649

Dangaran, K., Tomasula, P. M., \& Qi, P. (2009). Structure and Function of Protein-Based Edible Films and Coatings. In M. E. Embuscado \& K. C. Huber (Eds.), Edible Films and Coatings for Food Applications. Springer (pp. 25-56), https://www.researchgate.net/publica tion/253174398_Edible_Films_and Coatings_for_Food_Applications

Dhanapal, A., Rajamani, L., \& Banu, M. (2012). Edible films from Polysaccharides. Food Science and Quality, 3(1), 9-18, https://www.iiste.org/Journals/index. php/FSQM/article/view/1057

Homez- Jara, A., Daza, L. D., Aguirre, D. M., Muñoz, J. A., Solanilla, J. F., \& Váquiro, H. A. (2018). Characterization of chitosan edible films obtained with various polymer concentrations and drying temperatures. International Journal of Biological Macromolecules, 113, 1233-1240,

https://doi.org/10.1016/j.ijbiomac.20 18.03.057

Horwitz, W., \& Latimer, G. W. (2005). Official methods of analysis of AOAC International. AOAC International.

Kamsiati, E., Herawati, H., \& Purwani, E. Y. (2017). Potensi Pengembangan Plastik Biodegradable Berbasis Pati Sagu dan Ubi kayu di Indonesia. Jurnal Penelitian Dan Pengembangan Pertanian, 36(2), 67, http://dx.doi.org/10.21082/jp3.v36n2 2017.p67-76

Madjaga, B. H., Nurhaeni, N., \& Ruslan, R. (2017). Optimalisasi Ekstraksi Pektin dari Kulit Buah Sukun (Artocarpus altilis). Kovalen, 3(2), 158 ,

http://jurnal.untad.ac.id/jurnal/index. $\mathrm{php} / \mathrm{kovalen} /$ article/view/8722

Muin, R., Anggraini, D., \& Malau, F. (2017). Karakteristik Fisik dan Antimikroba Edible Film Dari Tepung Tapioka Dengan Penambahan Gliserol dan Kunyit Putih. Jurnal Teknik Kimia, 23(3), 191-198,

http://ejournal.ft.unsri.ac.id/index.ph $\mathrm{p} / \mathrm{jtk} /$ article/view/60

Ningrum, E. O., Ardiani, L., Rohmah, N. A., \& Fajar, N. (2019). Modifikasi Biokomposit Kitosan dari Cangkang Rajungan ( Portunus Pelagicus ) dan Pektin untuk Aplikasi Edible Film. Prosiding Seminar Nasional Teknik Kimia "Kejuangan" Pengembangan Teknologi Kimia Untuk Pengolahan Sumber Daya Alam Indonesia, 25 April, 4-9, http://jurnal.upnyk.ac.id/index.php/k ejuangan/article/view/2820

Nordby, M. H., Kjøniksen, A. L., Nyström, B., \& Roots, J. (2003). Thermoreversible gelation of aqueous mixtures of pectin and chitosan. Rheology. Biomacromolecules, 4(2), 337-343. https://doi.org/10.1021/bm020107+

Putra, A. D, Johan, V. S, \& Efendi, R. (2017). Penambahan Sorbitol Sebagai Plasticizer Dalam Pembuatan Edible Film Pati Sukun. JOM Fakultas Pertanian, 4(2), 1-15, https://jom.unri.ac.id/index.php/JOM FAPERTA/article/view/17053

Rochima, E. (2014). Kajian Pemanfaatan Limbah Rajungan dan Aplikasinya Untuk Bahan Minuman Kesehatan Berbasis Kitosan. Jurnal Akuatika Indonesia, $\quad 5(1), \quad 71-82$, 
Karakteristik Biokomposit Edible Film dari Campuran Kitosan dan Pektin Limbah Kulit Pisang Kepok (Musa acuminata)

http://jurnal.unpad.ac.id/akuatika/arti cle/view/3707

Santoso, B., Pratama, F., Hamzah, B., \& Pambayun, R. (2012). Perbaikan Sifat Mekanik dan Laju Transmisi Uap Air Edible Film dari Pati Ganyong Termodifikasi dengan Menggunakan Lilin Lebah dan Surfaktan. Agritech, 32(1), 9-14, https://jurnal.ugm.ac.id/agritech/artic le/view/9650

Saputro, A. N. C., \& Ovita, A. L. (2017). Sintesis dan karakterisasi bioplastik dari kitosan-pati ganyong (Canna edulis). Kimia dan Pendidikan Kimia, 2(1), 13-21, https://jurnal.uns.ac.id/jkpk/article/vi ew/8526/9842

Setiani, W., Sudiarti, T., \& Rahmidar, L. (2013). Preparation and Characterization of Edible Films from Poliblend Pati Sukun-Kitosan. Valensi, 3(2), 100-109, http://journal.uinjkt.ac.id/index.php/v alensi/article/view/506/0

Sirotek, K., Slováková, L., Kopečný, J., \& Marounek, M. (2004). Fermentation of pectin and glucose, and activity of pectin-degrading enzymes in the rabbit caecal bacterium Bacteroides caccae. Letters in Applied Microbiology, 38(4), 327-332, https://doi.org/10.1111/j.1472765X.2004.01492.X

Suprioto, F. (2010). Pengembangan Edible Film Komposit Pektin/Kitosan Dengan Polietilen Glikol (Peg) Sebagai Plasticizer. Skripsi, Bogor: Institut Pertanian Bogor, https://repository.ipb.ac.id/jspui/bitst ream/123456789/59823/1/F10fsu.pdf Tobing, M. T. L., Basid, N., \& Prasetya, A. (2011). Peningkatan Derajat Deasetilasi Kitosan dari Cangkang Rajungan. Jurnal Kimia Sains Dan Aplikasi, 14(3), 83-88, https://doi.org/10.14710/jksa.14.3.83 $\underline{-88}$

Tuhuloula, A., Budiyarti, L., \& Fitriana, E. N. (2013). Karakterisasi Pektin
Dengan Memanfaatkan Limbah Kulit Pisang Menggunakan Metode Ekstraksi. Jurnal Konversi, 2(1), 2127 , https://ppjp.ulm.ac.id/journal/index.p hp/konversi/article/view/123 